(c) American Dairy Science Association, 2003.

\title{
Effects of Corn Silage Hybrid and Dietary Concentration of Forage NDF on Digestibility and Performance by Dairy Cows ${ }^{1}$
}

\author{
X. Qiu, M. L. Eastridge, and Z. Wang \\ Department of Animal Sciences, The Ohio State University, Columbus 43210
}

\begin{abstract}
Eight intact multiparous cows and four ruminally and duodenally cannulated primiparous cows were fed four diets in a replicated $4 \times 4$ Latin square design: 1 ) $17 \%$ forage neutral detergent fiber (NDF) with brown midrib corn silage (BMRCS), 2) 21\% forage NDF with BMRCS, 3) $17 \%$ forage NDF with conventional corn silage (CCS), and 4) $21 \%$ forage NDF with CCS. Diets contained $17.4 \%$ crude protein and $38.5 \%$ NDF. Each period consisted of $4 \mathrm{wk}$ for intact cows and 2 wk for cannulated cows. For intact cows, DM intake was higher for BMRCS than CCS, and milk urea N was higher for 21 than $17 \%$ forage NDF. Milk protein yield tended to be higher and milk urea $\mathrm{N}$ lower for cows fed BMRCS than those fed CCS. Milk yield and milk protein percentage were similar among treatments. For the cannulated cows, ruminal mat consistency was similar among treatments. Based on a $72 \mathrm{~h}$ in situ incubation, BMRCS was lower in indigestible NDF than CCS. The BMRCS resulted in a higher proportion of ruminal propionate than CCS. Cows fed $21 \%$ forage NDF had a higher proportion of acetate and a lower proportion of propionate than cows fed $17 \%$ forage NDF. The total tract digestibility of nutrients and efficiency of bacterial $\mathrm{N}$ synthesis were similar among treatments, except that BMRCS resulted in lower intestinal fatty acid digestibility than CCS, and $17 \%$ forage NDF tended to result in higher total tract fatty acid digestibility than $21 \%$ forage NDF. Ruminal NDF digestibility was similar among dietary treatments. The increased milk production observed from feeding BMRCS in some studies may be explained by higher DM intake rather than increased total tract digestibility of the diets.
\end{abstract}

(Key words: brown midrib, corn silage, forage NDF)

Abbreviation key: BMR = brown midrib, BMRCS = brown midrib corn silage, $\mathbf{C C S}=$ conventional corn si-

Received October 12, 2002.

Accepted April 23, 2003.

Corresponding author: M. L. Eastridge; e-mail: eastridge.1@ osu.edu.

${ }^{1}$ Salaries and research support provided by State and Federal funds appropriated to the Ohio Agricultural Research and Development Center, The Ohio State University. lage, $\mathbf{C S}=$ corn silage, $\mathbf{F A}=$ fatty acid, $\mathbf{F N D F}=$ forage NDF.

\section{INTRODUCTION}

Corn silage (CS) hybrids with the brown midrib (BMR) gene have been proposed to be good forage sources when DMI is a particular concern, such as with high-producing cows (Oba and Allen, 1999; Oba and Allen, 2000a). The BMR CS (BMRCS) consistently has a lower lignin concentration and an increased in vitro digestibility of NDF, with little difference in NDF and protein concentrations, compared to conventional CS (CCS) (Cherney et al., 1991). Cows in early lactation tend to be in negative energy balance, and gut fill is considered to be one of the factors limiting energy intake by dairy cows (Allen, 1996). An enhanced NDF digestibility has been speculated to increase DMI, and thus energy intake, when the maximum intake is limited by physical fill.

Eastridge (1999) summarized several studies and showed that inclusion of BMRCS in diets consistently increased DMI by cows, ranging from 0.4 to $3.3 \mathrm{~kg} / \mathrm{d}$. However, milk yield responses were more variable than DMI responses. Cows fed BMRCS produced $1.0 \mathrm{~kg} / \mathrm{d}$ more milk than cows fed the control silage (Eastridge, 1999), but some studies have not resulted in a positive response in milk yield by feeding BMRCS (Rook et al., 1977; Sommerfelt et al., 1979; Block et al., 1981).

The use of BMRCS in diets with low forage NDF (FNDF) has been anecdotally questioned because BMRCS has higher in vitro NDF digestibility. However, there is no documented justification to support this potential concern. Oba and Allen (2000c) found that although in vitro NDF digestibility of BMRCS was higher than for CCS, enhanced in vitro NDF digestibility does not necessarily translate to increased NDF digestibility either in the rumen or in the total tract. However, BMRCS may possibly increase DMI and rate of passage, thus improving efficiency of microbial protein production. Oba and Allen (2000a) also observed that BMRCS depressed milk fat percentage when fed in a low NDF diet. However, the question remains whether milk fat percentage is more responsive to total dietary NDF or dietary FNDF, particularly when BMRCS is fed to lac- 
tating cows. We hypothesized that BMRCS can be effectively used in low forage diets as long as sufficient dietary NDF and FNDF are provided. The objective of this study was to determine whether BMRCS interacts with concentration of dietary FNDF to affect ruminal fermentation, nutrient digestibility, and animal performance.

\section{MATERIALS AND METHODS}

\section{Corn Silage}

During spring 1997, two CS hybrids, Cargill 6208FQ and Cargill 657 (Cargill Hybrid Seeds, Minneapolis, $\mathrm{MN}$ ), were planted in adjacent fields on the Waterman Farm at The Ohio State University (Columbus). Except for the $b m 3$ mutation, Cargill 657 was isogenic to Cargill $6208 \mathrm{FQ}$. Yields were measured by collecting the forage from one thousandth of an acre in four different rows within two locations of the field for each hybrid. The conventional and BMR hybrids were harvested and chopped on September 3 and September 10, respectively, when the corn grain reached $23 \%$ and $43 \%$ milk line, respectively, and the whole plant contained about $30 \%$ DM. Both hybrids were ensiled separately in 2.4 $\times 60 \mathrm{~m}$ plastic bags (Ag-Bag Corporation, Astoria, OR).

\section{Animals, Diets, and Experimental Design}

Four ruminally and duodenally cannulated primiparous cows (average DIM $=49$ ) and eight intact multiparous cows (average DIM $=162$ ) were used in two separate $4 \times 4$ Latin Squares. The treatments were: 1) $17 \%$ FNDF with BMRCS, 2) 21\% FNDF with BMRCS, 3) $17 \%$ FNDF with CCS, and 4) $21 \%$ FNDF with CCS. The diets contained $17.3 \% \mathrm{CP}$ and $38.5 \% \mathrm{NDF}$, with soybean hulls providing 23.4 and $17.8 \%$ of DM for 17 and $21 \%$ FNDF diets, respectively (Table 1). About $75 \%$ of the forage was from CS and $25 \%$ from alfalfa silage. Diets were prepared once a day as TMR, and all cows were fed individually twice a day at $0700 \mathrm{~h}$ and $1900 \mathrm{~h}$ for ad libitum intake. The CS and alfalfa silage samples were taken weekly, and concentrates were sampled biweekly to determine $\mathrm{DM}$ concentration at $55^{\circ} \mathrm{C}$ and to adjust the ration accordingly.

\section{Sampling Methods}

For the cannulated cows, each period consisted of 14 $\mathrm{d}$ with the last $7 \mathrm{~d}$ used for collection of milk yield and DMI data. The last $4 \mathrm{~d}$ of each period were used for collection of milk composition and digestibility data. Feed offered and refused were sampled daily during $d$ 11 through 14 and were composited for determination of DM, OM, N, NDF, ADF, starch, and fatty acid (FA) concentrations for the collection period. Feed offered was sampled immediately before the pm feeding, and feed refusals were collected, weighed, and sampled at about 1630 h each day. Digestibility of feed components was determined by the use of $\mathrm{Cr}_{2} \mathrm{O}_{3}$, which was dosed in the rumen twice daily from d 5 through $d 14$ at each feeding at $100 \mathrm{~g}$ per dose in the form of a pellet. The pellets contained $5 \% \mathrm{Cr}_{2} \mathrm{O}_{3}$, with the carrier being soybean hulls. Milk samples were taken at both am and pm milkings on two alternating days for determination of milk fat and protein.

On d 10 of each period, ruminal mat consistency was measured (Vaage and Milligan, 1993; Welch, 1982). A weight of exactly $0.454 \mathrm{~kg}$ was put at the bottom of the rumen at each feeding, with one end of the attached string left outside the rumen. At $3 \mathrm{~h}$ postfeeding, the free end of the string was pulled through two pulleys mounted on both ends of a board. A weight of 2.27 $\mathrm{kg}$ was hooked onto the end of the string. After the counterweight was engaged, the distance the weight inside the rumen traveled through the ruminal mat was recorded every $20 \mathrm{~s}$.

Nylon bags $(10 \times 20 \mathrm{~cm}$ and approximately $50 \mu \mathrm{m}$ pore size; Ankom, Fairport, NY) were dried for at least $3 \mathrm{~h}$ at $55^{\circ} \mathrm{C}$ and air equilibrated for about $0.5 \mathrm{~h}$. Approximately $2 \mathrm{~g}$ of CS of CCS or BMR type were measured into the nylon bags. The CS was dried at $55^{\circ} \mathrm{C}$ and ground through a 2-mm Wiley Mill screen (Arthur A. Thomas, Philadelphia, PA). Incubation started immediately prior to the 0700 -h feeding on $\mathrm{d} 11$ of each period. The bags were briefly soaked in cold tap water and then submerged about $30 \mathrm{~cm}$ into the ruminal contents. Bags ( $\mathrm{n}=2$ per time point) were removed at $0,3,6,12,24$, 48 , and $72 \mathrm{~h}$ of incubation. After removal, bags were placed in cold water to slow the fermentation, and then the bags were rinsed thoroughly in running cool tap water to remove the external feed particles. Samples were frozen for later analyses.

Ruminal samples for determination of $\mathrm{pH}, \mathrm{NH}_{3}-\mathrm{N}$, and VFA were taken on the last $2 \mathrm{~d}$ of each period at $3,6,9$, and $12 \mathrm{~h}$ post feeding. Approximately $500 \mathrm{ml}$ of ruminal contents were collected; after measuring $\mathrm{pH}$ of the ruminal fluid, $50 \mathrm{ml}$ were filtered through four layers of cheese cloth, and $3 \mathrm{ml}$ of $6 \mathrm{~N} \mathrm{HCl}$ were added to the $50 \mathrm{ml}$ of ruminal fluid to stop fermentation. Ruminal fluid samples were composited and frozen until later analyses for VFA and $\mathrm{NH}_{3}-\mathrm{N}$.

Ruminal samples for harvesting of bacteria were taken at $3,6,9$, and $12 \mathrm{~h}$ on $\mathrm{d} 11,12,13$, and 14 , respectively, of each period. Approximately $600 \mathrm{ml}$ of ruminal contents were placed in a blender. A $0.9 \%$ saline solution was added to create a slurry, and the mixture was blended at low speed for $1 \mathrm{~min}$ to detach some of the particle-associated bacteria from the feed parti- 
Table 1. Ingredient and chemical composition of experimental diets.

\begin{tabular}{|c|c|c|c|c|}
\hline \multirow[b]{2}{*}{ Item } & \multicolumn{4}{|c|}{ Treatment $^{1}$} \\
\hline & 17BMRCS & 21BMRCS & 17CCS & $21 \mathrm{CCS}$ \\
\hline & & $-(\%$ & & \\
\hline \multicolumn{5}{|l|}{ Ingredient composition } \\
\hline Alfalfa silage & 10.40 & 12.59 & 10.40 & 12.59 \\
\hline BMRCS & 31.50 & 39.12 & - & - \\
\hline CCS & - & - & 31.50 & 39.12 \\
\hline Dry shelled corn, ground & 12.95 & 7.41 & 12.95 & 7.41 \\
\hline Soybean hulls & 23.39 & 17.80 & 23.39 & 17.80 \\
\hline Soybean meal, $44 \% \mathrm{CP}$ & 14.80 & 16.40 & 14.80 & 16.40 \\
\hline Blood meal & 1.33 & 1.33 & 1.33 & 1.33 \\
\hline Tallow & 2.04 & 2.04 & 2.04 & 2.04 \\
\hline Dicalcium phosphate & 0.50 & 0.44 & 0.50 & 0.44 \\
\hline Feed grade limestone & 1.08 & 1.06 & 1.08 & 1.06 \\
\hline Magnesium oxide & 0.12 & 0.12 & 0.12 & 0.12 \\
\hline Trace mineralized salt & 0.52 & 0.52 & 0.52 & 0.52 \\
\hline Potassium sulfate & 0.15 & 0.12 & 0.15 & 0.12 \\
\hline Sodium bicarbonate & 0.79 & 0.80 & 0.79 & 0.80 \\
\hline Feed grade urea & 0.33 & 0.15 & 0.33 & 0.15 \\
\hline Vitamin supplements $^{2}$ & 0.10 & 0.10 & 0.10 & 0.10 \\
\hline \multicolumn{5}{|l|}{ Chemical composition } \\
\hline $\mathrm{NDF}$ & 40.0 & 37.2 & 38.1 & 38.5 \\
\hline FNDF & 17.1 & 21.2 & 17.1 & 21.2 \\
\hline $\mathrm{ADF}$ & 28.1 & 25.6 & 27.1 & 27.9 \\
\hline $\mathrm{CP}$ & 17.2 & 17.4 & 17.3 & 17.4 \\
\hline $\mathrm{NE}_{\mathrm{L}},{ }^{3} \mathrm{Mcal} / \mathrm{kg}$ & 1.74 & 1.72 & 1.74 & 1.72 \\
\hline Fatty acids & 3.38 & 3.47 & 3.37 & 3.33 \\
\hline Starch & 32.7 & 33.6 & 32.8 & 32.6 \\
\hline Ash & 6.45 & 6.50 & 6.51 & 6.54 \\
\hline $\mathrm{P}$ & 0.40 & 0.41 & 0.41 & 0.42 \\
\hline $\mathrm{K}$ & 1.41 & 1.44 & 1.40 & 1.47 \\
\hline $\mathrm{Ca}$ & 0.96 & 1.01 & 1.01 & 1.00 \\
\hline $\mathrm{Mg}$ & 0.26 & 0.27 & 0.27 & 0.27 \\
\hline
\end{tabular}

${ }^{1} 17 \mathrm{BMRCS}=17 \%$ forage $\mathrm{NDF}(\mathrm{FNDF})$ with brown midrib corn silage (BMRCS); $21 \mathrm{BMRCS}=21 \% \mathrm{FNDF}$ with BMRCS; $17 \mathrm{CCS}=17 \%$ FNDF with conventional corn silage (CCS); and $21 \mathrm{CCS}=21 \%$ FNDF with CCS.

${ }^{2} 0.02 \%$ vitamin A (30,000 IU/g), $0.02 \%$ vitamin D (3000 IU/g), and $0.06 \%$ vitamin $\mathrm{E}(44 \mathrm{IU} / \mathrm{g})$.

${ }^{3}$ Calculated using NRC (1989) values for feeds.

cles. The mixture of ruminal contents and saline solution was then filtered with eight layers of cheese cloth. After filtration, $500 \mathrm{ml}$ of fluid were collected, composited for each day of the collection period, and frozen for later analyses.

Duodenal samples were taken every $6 \mathrm{~h}$ during the 4-d collection period, with the starting time being altered by $1.5 \mathrm{~h}$ each day. About $280 \mathrm{ml}$ of duodenal contents were collected, composited for each day of the collection period, and stored in a freezer at $-20^{\circ} \mathrm{C}$. Later, samples were thawed and subsampled while blending. Samples were frozen for later analyses of OM, NDF, N, $\mathrm{NH}_{3}-\mathrm{N}, \mathrm{FA}, \mathrm{Cr}$, and purines.

Fecal samples were taken every $12 \mathrm{~h}$ during the 4-d collection period, with the starting time being altered by $3 \mathrm{~h}$ each day. Samples of feces were frozen and later analyzed for OM, NDF, N, FA, and Cr. Representative samples of feed offered, feed refused, duodenal contents, and feces taken during the collection period were lyophilized, composited, and ground through a $2-\mathrm{mm}$ screen in a Wiley mill prior to lab analysis.
The eight intact cows were fed each diet for $4 \mathrm{wk}$, with the last 2 wk used for sample collection. Milk yield and DMI were recorded daily, and milk was sampled twice weekly. Body weight was recorded weekly. Chewing activity by intact cows was observed for $24 \mathrm{~h}$ two consecutive times during period four of the study.

\section{Laboratory Procedures}

To standardize DMI for fluctuating DM concentration, 200- to 250-g representative samples of feed offered and refused were dried in an oven at $55^{\circ} \mathrm{C}$ for $72 \mathrm{~h}$. Chromium concentrations of duodenal and fecal samples were determined as described by Williams et al. (1962) using a Varian SpectrAA Atomic Absorption Spectrometer 220 (Varian Australia Pty Ltd., Mulgrave, Australia). Purine concentrations of rumen bacteria and duodenal contents were used to determine microbial flow to the duodenum (Ushida et al., 1985; Zinn and Owens, 1986). Nitrogen concentrations of feed, digesta, and rumen bacteria were determined ac- 
cording to Bremner and Mulvaney (1982) using a Tecator Digestion 20 System, 1015 Digestor and a Tecator Kjeltec System, 1026 Distilling Unit (Tecator AB, Hoganas, Sweden). Analysis of fiber components was according to Goering and Van Soest (1970) and more recent modifications to the NDF procedure (Van Soest et al., 1991). To minimize the interference by fat with the fiber analysis, all feed and digesta samples were filtered with $100 \mathrm{ml}$ of boiling ethanol prior to treatment in 30 $\mathrm{ml}$ of $8 M$ urea and $0.2 \mathrm{ml} \alpha$-amylase (Sigma A-5426; Sigma Chemical Co., St. Louis, MO). Starch was determined as described by Wang et al. (2001). Individual minerals were analyzed by inductively coupled plasma spectrometry at the Research Extension Analytical Laboratory (Wooster, $\mathrm{OH}$ ).

In situ samples were thawed and dried at $55^{\circ} \mathrm{C}$ for at least $48 \mathrm{~h}$. Residual matter was analyzed for NDF. Percentage of NDF of the original sample of CS was determined and used to calculate percentage of indigestible NDF. The NDF residues at $72 \mathrm{~h}$ were used to calculate potentially digestible NDF.

Ruminal fluid samples were thawed, mixed, and centrifuged at $15,000 \times g$, and the supernatant was filtered through Waterman \#1 paper. The filtered supernatant was saved for later analysis of $\mathrm{NH}_{3}-\mathrm{N}$ and VFA. A Hewlett Packard 5890, Series II (Hewlett-Packard Company, Avondale, PA) GLC with an HP 3396A Integrater (Hewlett-Packard Company) was used for all VFA analyses. The GLC was equipped with a 1.8-m glass column packed with GP $10 \% \mathrm{SP}-1200 / 1 \% \mathrm{H}_{3} \mathrm{PO}_{4}$ on $80 / 100$ Chromosorb WAW (Supelco, Inc. Bellefonte, PA). The internal standard used was 2-ethylbutyric acid, and $\mathrm{N}$ was the carrier gas. Injector port temperature was $185^{\circ} \mathrm{C}$, and the detector port was set at $195^{\circ} \mathrm{C}$. The column was held at $115^{\circ} \mathrm{C}$ for $8 \mathrm{~min}$.

Feed offered, feed refused, duodenal contents, feces, and bacteria samples were analyzed for FA according to the procedure described by Sukhija and Palmquist (1988). Milk FA was analyzed according to some modifications of this procedure. Milk fat was collected by centrifugation of 12 to $15 \mathrm{ml}$ of milk at $8000 \times g$ to form a solid milk fat layer on top of the milk, and $100 \mathrm{mg}$ of milk fat were used for analyses. Two milliliters of hexane were used as a solvent instead of benzene. Methylation occurred by heating samples for $1.5 \mathrm{~h}$ at $50^{\circ} \mathrm{C}$. After removal of the solvent layer, $1.0 \mathrm{ml}$ of hexane was added to the original culture tube, samples were again mixed and centrifuged, and the solvent layer was removed and composited with the first solvent layer. Approximately $0.5 \mathrm{~g}$ anhydrous sodium sulfate was added to the composited sample, and the sample was vortexed again and let stand for $0.5 \mathrm{~h}$ prior to the final centrifugation.
The GLC was equipped with a $30-\mathrm{m}, 0.25-\mathrm{mm}$ ID, $10 \%$ SP-2380 fused silica capillary column (Supelco, Inc., Bellefonte, PA) for analysis of all feed, digesta, bacteria, and milk FA. For feed, digesta, and bacteria FA, the injector port temperature was $230^{\circ} \mathrm{C}$ and the detector port was set at $250^{\circ} \mathrm{C}$. The column was held at $165^{\circ} \mathrm{C}$ for $13 \mathrm{~min}$ and then increased at $2.5^{\circ} \mathrm{C} / \mathrm{min}$ to $200^{\circ} \mathrm{C}$ and held for an additional $2 \mathrm{~min}$. For milk FA, the injector port temperature was $240^{\circ} \mathrm{C}$ and the detector port was $250^{\circ} \mathrm{C}$. The column was held at $60^{\circ} \mathrm{C}$ for $4 \mathrm{~min}$, then increased at $3^{\circ} \mathrm{C} / \mathrm{min}$ to $165^{\circ} \mathrm{C}$, then increased at $1^{\circ} \mathrm{C} / \mathrm{min}$ up to $180^{\circ} \mathrm{C}$, held for $7 \mathrm{~min}$, then increased at $5^{\circ} \mathrm{C} / \mathrm{min}$ up to $210^{\circ} \mathrm{C}$ and held for an additional $5 \mathrm{~min}$. Milk fat and true protein were determined using infrared spectroscopy, and milk urea $\mathrm{N}$ was determined by using a Skalar SAN Plus segmented flow analyzer (Skalar, Inc., Norcross, GA) at the DHI Laboratory (DHI Cooperative, Inc., Columbus, $\mathrm{OH}$ ).

\section{Statistical Analysis}

Treatments were arranged in a $2 \times 2$ factorial design for a replicated $4 \times 4$ Latin square. All statistical analyses of the data except those of ruminal $\mathrm{pH}$ and VFA were performed using the general linear model procedure of SAS (1997). Effects of square, cow, period, and dietary treatment were tested. Data for ruminal $\mathrm{pH}$ and VFA were analyzed with the MIXED model procedure of SAS (1997) with repeated measures for time of sampling. Cow was classified as a random effect. The first-order autoregressive [AR(1)] type was selected as the appropriate covariance structure for the repeated measures. Contrasts were made for: 1) BMRCS versus CCS, 2) 17 versus $21 \% \mathrm{FNDF}$, and 3 ) the interaction of CS hybrids and dietary level of FNDF. Significance was declared when $P<0.05$, and tendency was stated when $0.05<$ $P \leq 0.10$.

\section{RESULTS AND DISCUSSION}

\section{Chemical Composition of Diets and Corn Hybrids}

Diets contained $38.5 \% \mathrm{NDF}, 17.3 \% \mathrm{CP}$, and $32.9 \%$ starch (Table 1). Chemical composition of the BMR and conventional corn hybrids and the silage made from them was similar except that the BMR corn and its silage had lower lignin concentrations (Table 2). The forage yield of BMR corn was about $13.5 \%$ lower than that for the conventional corn.

\section{DMI, Milk Yield, and Milk Components}

For the intact cows, consistent with previous studies (Eastridge, 1999), DMI was higher for BMRCS than CCS (Table 3). There was an interaction between FNDF 
Table 2. Composition and yield of corn for silage. ${ }^{1}$

\begin{tabular}{lccccc}
\hline & \multicolumn{2}{c}{ Nonensiled Corn } & & \multicolumn{2}{c}{ Corn Silage } \\
\cline { 2 - 3 } \cline { 5 - 6 } & BMRC & CC & & BMRCS & CCS \\
\hline DM, \% & 31.4 & 28.6 & & 35.6 & 33.5 \\
DM yield, t/ha & 15.4 & 17.8 & & - & - \\
Ear, \% of DM & 42.6 & 51.7 & & - & - \\
Stover, \% of DM & 57.4 & 48.3 & - & - \\
\cline { 2 - 3 } & & & & & - \\
CP & 7.24 & 7.48 & & 7.67 & 7.76 \\
NDF & 45.9 & 44.5 & & 41.6 & 41.1 \\
ADF & 24.2 & 24.3 & & 27.2 & 26.6 \\
Lignin & 1.14 & 2.12 & & 1.13 & 2.34 \\
Starch & 34.8 & 33.9 & & 33.1 & 31.6 \\
Ash & 4.12 & 4.04 & & 4.18 & 4.04 \\
\hline
\end{tabular}

${ }^{1} \mathrm{BMRC}=$ brown midrib corn, BMRCS = brown midrib corn silage, $\mathrm{CC}=$ conventional corn, and CCS $=$ conventional corn silage .

and CS for DMI. This interaction revealed that the higher level of inclusion of CCS decreased DMI, but an increase in BMRCS in the diet did not decrease DMI, possibly because of higher digestibility of the silage NDF (Table 6) or higher passage rate. Oba and Allen (2000a) hypothesized that reducing physical fill in the rumen by feeding more degradable NDF increases DMI and productivity to a greater extent when animals are fed a high NDF compared to a low NDF diet. The data from our study would support the increase in DMI, but not milk production, with BMRCS compared with CCS in a high NDF diet.

Milk yield was similar among treatments. Previous studies showed that, although inclusion of BMRCS in diets consistently resulted in higher DMI, milk yield responses were more variable than DMI responses. In some studies, milk yield increased by feeding BMRCS (Keith et al., 1979; Oba and Allen, 1999), but other studies did not find a positive response (Rook et al.,
1977; Stallings et al., 1982). In a recent study, Tjardes et al. (2000) observed that BMRCS improved total tract digestibility of $\mathrm{OM}$ and NDF but not performance by growing beef steers.

An interaction occurred between silage and FNDF for milk fat percentage. Increasing concentration of FNDF with BMRCS increased milk fat percentage but decreased it with CCS. Milk fat yield and milk protein percentage were similar among treatments, but milk protein yield tended to be higher for BMRCS than CCS. The MUN was higher for 21 than $17 \%$ FNDF but tended to be lower for BMRCS than CCS. For the cannulated cows, milk yield and milk protein yield were higher for BMRCS than CCS (data not shown). Because the cannulated cows were fed each diet for only half as long as the intact cows ( 2 versus $4 \mathrm{wk}$ ), the DMI, milk yield, and milk composition yield from these cows were not included in Table 3. However, these results accentuated the observation that milk yield responses of feeding BMRCS are more variable than DMI responses.

\section{Ruminal Fermentation Characteristics and Mat Consistency}

Ruminal $\mathrm{pH}$ was similar among treatments, but cows fed BMRCS had a higher proportion of ruminal propionate than cows fed CCS (Table 4). Cows fed 21\% FNDF had a higher proportion of acetate and lower proportion of propionate than cows fed $17 \%$ FNDF. The proportion of butyrate was higher for cows fed CCS than those fed BMRCS. The acetate:propionate ratio was lower for BMRCS than CCS and 17 than $21 \%$ FNDF.

Ruminal mat consistency was similar among main effects, but there tended $(P=0.06)$ to be an interaction between CS hybrids and FNDF in total ascension time (Table 5), with the shortest retention time occurring for

Table 3. Effect of corn silage hybrid and dietary level of forage NDF on DMI and performance by intact lactating cows.

\begin{tabular}{|c|c|c|c|c|c|c|c|c|}
\hline & \multicolumn{4}{|c|}{ Treatment $^{1}$} & \multirow[b]{2}{*}{ SE } & \multicolumn{3}{|c|}{ Probability $^{2}$} \\
\hline & 17BMRCS & 21BMRCS & $17 \mathrm{CCS}$ & 21CCS & & Silage & FNDF & $\mathrm{S} \times \mathrm{F}$ \\
\hline \multicolumn{9}{|l|}{ DMI, } \\
\hline $\mathrm{kg} / \mathrm{d}$ & 26.2 & 26.8 & 25.0 & 23.5 & 0.6 & $<0.01$ & 0.29 & 0.03 \\
\hline$\%$ of BW & 3.85 & 3.87 & 3.70 & 3.52 & 0.02 & 0.01 & 0.22 & 0.04 \\
\hline Milk yield, $\mathrm{kg} / \mathrm{d}$ & 35.5 & 35.5 & 34.0 & 34.1 & 1.2 & 0.11 & 0.96 & 0.93 \\
\hline $4 \% \mathrm{FCM}, \mathrm{kg} / \mathrm{d}$ & 34.1 & 35.0 & 33.5 & 32.9 & 1.2 & 0.14 & 0.88 & 0.38 \\
\hline Milk fat, $\%$ & 3.76 & 3.89 & 3.93 & 3.79 & 0.09 & 0.58 & 0.95 & 0.05 \\
\hline Milk fat, g/d & 1326 & 1387 & 1331 & 1285 & 53 & 0.21 & 0.84 & 0.17 \\
\hline Milk protein, \% & 3.31 & 3.29 & 3.28 & 3.35 & 0.04 & 0.62 & 0.44 & 0.11 \\
\hline Milk protein, g/d & 1167 & 1158 & 1110 & 1116 & 40 & 0.09 & 0.96 & 0.79 \\
\hline MUN, mg/dl & 15.9 & 17.3 & 16.6 & 18.1 & 0.5 & 0.06 & $<0.01$ & 0.83 \\
\hline
\end{tabular}

${ }^{1} 17 \mathrm{BMRCS}=17 \%$ forage NDF (FNDF) with brown midrib corn silage (BMRCS); $21 \mathrm{BMRCS}=21 \%$ FNDF with BMRCS; $17 \mathrm{CCS}=17 \%$ FNDF with conventional corn silage (CCS); and 21CCS $=21 \%$ FNDF with CCS.

${ }^{2}$ Silage $=$ main effect of corn silage hybrid; FNDF $=$ main effect of forage NDF level; and $\mathrm{S} \times \mathrm{F}=$ interaction between corn silage hybrid and FNDF level. 
Table 4. Effect of corn silage hybrid and dietary level of forage NDF on ruminal fermentation.

\begin{tabular}{|c|c|c|c|c|c|c|c|c|}
\hline & \multicolumn{4}{|c|}{ Treatment $^{1}$} & \multirow[b]{2}{*}{$\mathrm{SE}$} & \multicolumn{3}{|c|}{ Probability $^{2}$} \\
\hline & 17BMRCS & 21BMRCS & $17 \mathrm{CCS}$ & $21 \mathrm{CCS}$ & & Silage & FNDF & $\mathrm{S} \times \mathrm{F}$ \\
\hline $\mathrm{pH}$ & 5.78 & 6.02 & 5.93 & 5.81 & 0.11 & 0.68 & 0.45 & 0.11 \\
\hline Ammonia $\mathrm{N}, \mathrm{m} M$ & 16.0 & 14.8 & 17.1 & 17.9 & 1.4 & 0.41 & 0.92 & 0.69 \\
\hline Total VFA, $\mathrm{m} M$ & 121 & 120 & 112 & 118 & 3 & 0.30 & 0.57 & 0.51 \\
\hline Acetate, $\mathrm{mol} / 100 \mathrm{~mol}$ & 62.1 & 63.6 & 63.5 & 64.9 & 0.5 & 0.13 & 0.01 & 0.98 \\
\hline Propionate, $\mathrm{mol} / 100 \mathrm{~mol}$ & 24.3 & 22.8 & 21.7 & 20.8 & 0.7 & 0.03 & 0.05 & 0.78 \\
\hline Butyrate, $\mathrm{mol} / 100 \mathrm{~mol}$ & 9.9 & 10.1 & 10.7 & 10.7 & 0.2 & 0.03 & 0.59 & 0.74 \\
\hline Acetate:propionate & 2.56 & 2.79 & 2.93 & 3.12 & 0.13 & 0.03 & 0.05 & 0.90 \\
\hline
\end{tabular}

${ }^{1} 17 \mathrm{BMRCS}=17 \%$ forage $\mathrm{NDF}(\mathrm{FNDF})$ with brown midrib corn silage (BMRCS); $21 \mathrm{BMRCS}=21 \% \mathrm{FNDF}$ with BMRCS; 17CCS = 17\% FNDF with conventional corn silage (CCS); and 21CCS = 21\% FNDF with CCS.

${ }^{2}$ Silage $=$ main effect of corn silage hybrid; $\mathrm{FNDF}=$ main effect of forage NDF level; and $\mathrm{S} \times \mathrm{F}=$ interaction between corn silage hybrid and FNDF level.

$17 \%$ FNDF and BMRCS. Considerable variation among cows was noticed in terms of ruminal mat consistency measurements, with some cows always resulting in shorter total ascension times and others consistently resulting in longer retention times in spite of the different dietary treatments.

Oba and Allen (2000b) observed that enhanced NDF digestibility of CS did not decrease physical effectiveness of NDF. In the present study, feeding BMRCS at $17 \%$ FNDF did not alter the ruminal mat consistency of the cannulated cows, and total time spent chewing was similar among treatments based on observations with the intact cows ( $582 \mathrm{~min} / \mathrm{d}$ ). Ruminal fermentation was apparently not severely affected by this treatment based on ruminal $\mathrm{pH}$ being similar among treatments and the acetate-to-propionate ratio being greater than 2.5.

\section{In Situ NDF Disappearance and Dietary Nutrient Digestibility}

Potentially digestible NDF, calculated by subtracting NDF washout and NDF residuals after $72 \mathrm{~h}$ of in situ incubation, and rate of disappearance of potential di- gestible NDF were similar among treatments (Table 6). The NDF washout was higher for BMRCS than CCS. Indigestible NDF was lower for BMRCS than CCS because BMRCS was lower in lignin. It is not clear at this point why the NDF washout was higher for BMRCS than CCS. This may have occurred because some portion of the NDF in BMRCS was more fragile, thus easily broke into small particles and washed out of the in situ bags due to less extent of binding by lignin. If confirmed by further study, this feature may contribute to higher passage rate of BMRCS from the rumen and thus partially explain the higher DMI with feeding BMRCS.

The intake, duodenal and fecal flows, and digestibility of various dietary components are provided in Table 7. The intakes of $\mathrm{OM}$ and other dietary components were higher for 17 than 21\% FNDF and higher for BMRCS than CCS. The total tract digestibility of these components, except FA, and efficiency of microbial protein synthesis were similar among treatments. Stomach NDF digestibility was similar among dietary treatments. Rook et al. (1977) found an improvement in NDF digestibility by feeding BMRCS when the diet consisted of $60 \%$ forage and $40 \%$ concentrate, but NDF digestibility was lower for the BMRCS treatment than the control

Table 5. Effects of corn silage hybrid and dietary level of forage NDF on ruminal mat consistency.

\begin{tabular}{|c|c|c|c|c|c|c|c|c|}
\hline & \multicolumn{4}{|c|}{ Treatment $^{1}$} & \multirow[b]{2}{*}{$\mathrm{SE}$} & \multicolumn{3}{|c|}{ Probability $^{2}$} \\
\hline & 17BMRCS & 21BMRCS & $17 \mathrm{CCS}$ & $21 \mathrm{CCS}$ & & Silage & FNDF & $\mathrm{S} \times \mathrm{F}$ \\
\hline $\begin{array}{l}\text { Distance traveled } \\
\text { in first min, } \mathrm{cm}\end{array}$ & 14.0 & 11.3 & 15.3 & 13.4 & 2.8 & 0.40 & 0.25 & 0.83 \\
\hline $\begin{array}{l}\text { Rate after } 1 \mathrm{~min} \text {, } \\
\mathrm{cm} / \mathrm{min}\end{array}$ & 5.21 & 3.43 & 3.48 & 4.42 & 1.60 & 0.78 & 0.71 & 0.24 \\
\hline $\begin{array}{l}\text { Total ascension } \\
\text { time, min }\end{array}$ & 6.43 & 7.59 & 7.32 & 6.88 & 0.62 & 0.72 & 0.43 & 0.06 \\
\hline
\end{tabular}

${ }^{1} 17 \mathrm{BMRCS}=17 \%$ forage NDF (FNDF) with brown midrib corn silage (BMRCS); $21 \mathrm{BMRCS}=21 \%$ FNDF with BMRCS; $17 \mathrm{CCS}=17 \% \mathrm{FNDF}$ with conventional corn silage (CCS); and $21 \mathrm{CCS}=21 \% \mathrm{FNDF}$ with CCS.

${ }^{2}$ Silage $=$ main effect of corn silage hybrid; FNDF $=$ main effect of forage NDF level; and $\mathrm{S} \times \mathrm{F}=$ interaction between corn silage hybrid and FNDF level. 
Table 6. Effects of corn silage hybrid and dietary level of forage NDF on in situ disappearance of NDF in silage.

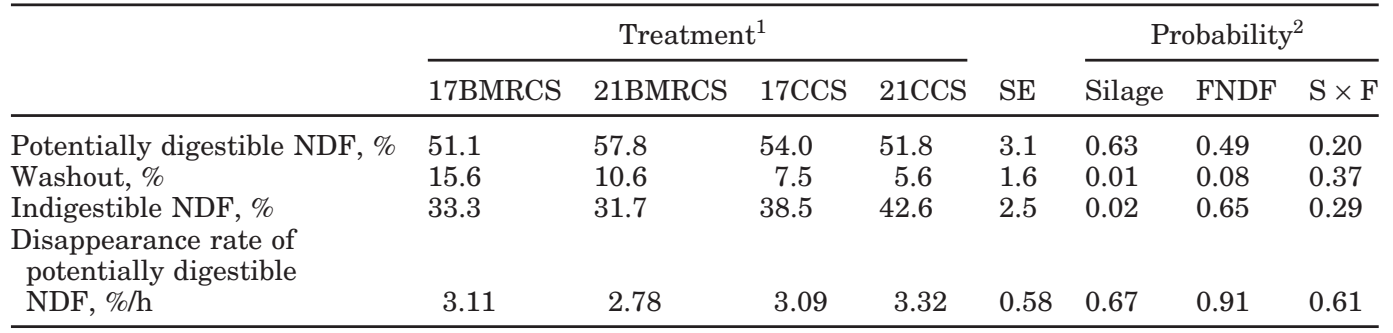

${ }^{1} 17 \mathrm{BMRCS}=17 \%$ forage NDF (FNDF) with brown midrib corn silage (BMRCS); $21 \mathrm{BMRCS}=21 \% \mathrm{FNDF}$ with BMRCS; $17 \mathrm{CCS}=17 \% \mathrm{FNDF}$ with conventional corn silage (CCS); and $21 \mathrm{CCS}=21 \%$ FNDF with CCS.

${ }^{2}$ Silage $=$ main effect of corn silage hybrid; FNDF = main effect of forage NDF level; and $\mathrm{S} \times \mathrm{F}=$ interaction between corn silage hybrid and FNDF level.

when the diet consisted of $96 \%$ forage and $4 \%$ concentrate. Oba and Allen (2000c) observed that, although in vitro NDF digestibility of BMRCS was higher than for CCS, enhanced in vitro NDF digestibility does not necessarily correlate with increased NDF digestibility either in the rumen or in the total tract. However, these

Table 7. Effects of corn silage hybrid and dietary level of forage NDF on nutrient digestibility by lactating cows.

\begin{tabular}{|c|c|c|c|c|c|c|c|c|}
\hline & \multicolumn{4}{|c|}{ Treatment $^{1}$} & SE & \multicolumn{3}{|c|}{ Probability $^{2}$} \\
\hline \multicolumn{9}{|l|}{$\mathrm{OM}$} \\
\hline Duodenal flow, kg/d & 9.91 & 9.02 & 8.79 & 8.23 & 0.62 & 0.18 & 0.29 & 0.76 \\
\hline Fecal flow, kg/d & 4.92 & 4.34 & 4.23 & 4.39 & 0.33 & 0.42 & 0.57 & 0.23 \\
\hline Apparent stomach digestibility, $\%$ of intake & 42.2 & 43.0 & 44.1 & 41.6 & 2.4 & 0.93 & 0.77 & 0.55 \\
\hline True stomach digestibility, $\%$ of intake & 60.2 & 63.8 & 65.8 & 63.1 & 2.3 & 0.36 & 0.87 & 0.25 \\
\hline \multicolumn{9}{|l|}{$\mathrm{NDF}$} \\
\hline Intake, $\mathrm{kg} / \mathrm{d}$ & 6.56 & 5.61 & 5.78 & 5.14 & 0.32 & 0.06 & 0.02 & 0.62 \\
\hline Stomach digestibility, $\%$ of intake & 54.7 & 54.8 & 52.6 & 46.5 & 2.9 & 0.15 & 0.38 & 0.36 \\
\hline Intestinal digestibility, $\%$ of intake & 13.3 & 8.5 & 12.4 & 9.8 & 2.8 & 0.94 & 0.26 & 0.73 \\
\hline Total tract digestibility, $\%$ of intake & 68.0 & 63.3 & 65.0 & 56.3 & 3.2 & 0.21 & 0.11 & 0.58 \\
\hline \multicolumn{9}{|l|}{ Nitrogen } \\
\hline Intake, $\mathrm{kg} / \mathrm{d}$ & 3.22 & 2.91 & 3.00 & 2.50 & 0.11 & 0.03 & 0.02 & 0.32 \\
\hline $\mathrm{g}$ of N/kg of OM truly digested & 26.3 & 27.7 & 28.2 & 28.3 & 2.1 & 0.60 & 0.75 & 0.79 \\
\hline Apparent intestinal digestibility, $\%$ of intake & 57.2 & 57.6 & 62.4 & 57.1 & 3.9 & 0.59 & 0.58 & 0.53 \\
\hline Apparent total tract digestibility, \% of intake & 74.8 & 75.6 & 75.9 & 71.5 & 2.0 & 0.53 & 0.45 & 0.29 \\
\hline \multicolumn{9}{|l|}{ Starch } \\
\hline Intake, $\mathrm{kg} / \mathrm{d}$ & 4.30 & 3.91 & 4.01 & 3.33 & 0.23 & 0.02 & 0.01 & 0.32 \\
\hline Duodenal flow, $\mathrm{kg} / \mathrm{d}$ & 1.11 & 1.02 & 0.82 & 0.73 & 0.15 & 0.09 & 0.73 & 0.84 \\
\hline Apparent stomach digestibility, $\%$ of intake & 75.7 & 74.7 & 80.2 & 78.7 & 3.4 & 0.30 & 0.75 & 0.95 \\
\hline Apparent intestinal digestibility, $\%$ of intake & 20.3 & 20.9 & 16.4 & 13.4 & 3.9 & 0.23 & 0.79 & 0.68 \\
\hline Apparent total tract digestibility, $\%$ of intake & 96.0 & 95.7 & 96.6 & 92.1 & 1.4 & 0.35 & 0.16 & 0.22 \\
\hline \multicolumn{9}{|l|}{ Fatty acids } \\
\hline Intake, $\mathrm{g} / \mathrm{d}$ & 619 & 585 & 576 & 508 & 16 & 0.02 & 0.03 & 0.35 \\
\hline Duodenal flow, g/d & 549 & 529 & 546 & 507 & 16 & 0.49 & 0.15 & 0.60 \\
\hline Apparent stomach digestibility, $\%$ of intake & 11.1 & 8.6 & 2.6 & 0.8 & 3.6 & 0.09 & 0.60 & 0.94 \\
\hline True stomach digestibility, $\%$ of intake & 41.1 & 40.0 & 35.2 & 39.1 & 0.3 & 0.34 & 0.68 & 0.47 \\
\hline
\end{tabular}

${ }^{1} 17 \mathrm{BMRCS}=17 \%$ forage NDF $(\mathrm{FNDF})$ with brown midrib corn silage (BMRCS); $21 \mathrm{BMRCS}=21 \%$ FNDF with BMRCS; $17 \mathrm{CCS}=17 \%$ FNDF with conventional corn silage (CCS); and $21 \mathrm{CCS}=21 \% \mathrm{FNDF}$ with CCS.

${ }^{2}$ Silage $=$ main effect of corn silage hybrid; FNDF = main effect of forage NDF level; and $\mathrm{S} \times \mathrm{F}=$ interaction between corn silage hybrid and FNDF level. 
authors concluded that NDF digestibility could possibly correlate with increased DMI and rate of passage and improved efficiency of microbial protein synthesis. When fed ad libitum, DMI was $2.4 \mathrm{~kg} / \mathrm{d}$ higher for cows fed a BMRCS diet compared with cows fed an isogenic diet, and when DMI was kept similar by limit feeding cows on BMRCS, apparent digestibilities of OM, NDF, and $\mathrm{ADF}$ were greater for cows fed BMRCS than cows fed the isogenic diet (Tine et al., 2001). In the present study, digestibilities of OM and NDF were not higher for BMRCS than CCS, possibly because of an increased DMI with BMRCS. The BMRCS resulted in lower intestinal FA digestibility than CCS, and 17\% FNDF tended to result in higher total tract digestibility of FA than $21 \%$ FNDF.

\section{CONCLUSIONS}

Compared to CCS, feeding BMRCS increased DMI and tended to increase milk protein yield. Responses on milk yield were more variable. The lower lignin concentration in BMRCS does not always result in a higher digestibility of dietary NDF either in rumen or total tract. Feeding BMRCS in low forage diets may not necessarily have adverse effects on ruminal fermentation and animal performance if dietary concentrations of total NDF, FNDF, and nonstructural carbohydrates are well balanced.

\section{ACKNOWLEDGMENTS}

Appreciation is expressed to Cargill, Inc., Minneapolis, MN for providing the seed corn and for partial funding of the project. The authors thank Andy Spring and John Lemmermen for their assistance with the care of the cows. Also, thanks is extended to Sue Zhang for assisting with laboratory analyses.

\section{REFERENCES}

Allen, M. S. 1996. Physical constraints on voluntary intake of forage by ruminants. J. Anim. Sci. 74:3063-3075.

Block, E., L. D. Muller, L. C. Griel, Jr., and D. L. Garwood. 1981. Brown midrib-3 corn silage and heat extruded soybeans for early lactating dairy cows. J. Dairy Sci. 64:1813-1825.

Bremner, J. M., and C. S. Mulvaney. 1982. Methods of soil analysis, Part 2. Chemical and microbiological properties. 2nd ed. Agronomy Monograph No. 9.

Cherney, J. H., D. J. R. Cherney, D. E. Akin, and J. D. Axtell. 1991. Potential of brown-midrib, low-lignin mutants for improving forage quality. Adv. Agron. 46:157-198.

Eastridge, M. L. 1999. Brown midrib corn silage. Pages 179-190 in Proc. Tri-State Dairy Nutrition Conference. The Ohio State University, Columbus.
Goering, H. K., and P. J. Van Soest. 1970. Forage Fiber Analysis (Apparatus, Reagents, Procedures, and some Applications). Agric. Handbook. No. 379. ARS-USDA, Washington, DC.

Keith, E. A., V. F. Colenbrander, V. L. Lechtenberg, and L. F. Bauman. 1979. Nutrition value of brown midrib corn silage for lactating dairy cows. J. Dairy Sci. 62:788-792.

National Research Council. 1989. Nutrient Requirements of Dairy Cattle. 6th rev. ed. Natl. Acad. Sci., Washington, DC.

Oba, M., and M. S. Allen. 1999. Effects of brown midrib 3 mutation in corn silage on dry matter intake and productivity of high yielding dairy cows. J. Dairy Sci. 82:135-142.

Oba, M., and M. S. Allen. 2000a. Effects of brown midrib 3 mutation in corn silage on productivity of dairy cows fed two concentrations of dietary neutral detergent fiber: 1 . Feeding behavior and nutrient utilization. J. Dairy Sci. 83:1333-1341.

Oba, M., and M. S. Allen. 2000b. Effects of brown midrib 3 mutation in corn silage on productivity of dairy cows fed two concentrations of dietary neutral detergent fiber: 2. Chewing activities. J. Dairy Sci. 83:1342-1349.

Oba, M., and M. S. Allen. 2000c. Effects of brown midrib 3 mutation in corn silage on productivity of dairy cows fed two concentrations of dietary neutral detergent fiber: 3. Digestibility and microbial efficiency. J. Dairy Sci. 83:1350-1358.

Rook, J. A., L. D. Muller, and D. B. Shank. 1977. Intake and digestibility of brown midrib corn silage by lactating dairy cows. J. Dairy Sci. 60:1894-1904.

SAS/STAT Software. 1997. Changes and Enhancements through Release 6.12. SAS Inst., Cary, NC.

Sommerfeldt, J. L., D. J. Schingoethe, and L. D. Muller. 1979. Brown midrib corn silage for lactating dairy cows. J. Dairy Sci. 62:1611-1618.

Stallings, C. C., B. M. Donaldson, J. W. Thomas, and E. C. Rossman. 1982. In vivo evaluation of brown midrib corn silage by sheep and lactating dairy cows. J. Dairy Sci. 65:1945-1949.

Sukhija, P. S., and D. L. Palmquist. 1988. Rapid method for determination of total fatty acid content and composition of feedstuffs and feces. J. Agric. Food Chem. 36:1202-1206.

Tine, M. A., K. R. Mcleod, R. A. Erdman, and R. L. Baldwin. 2001. Effects of brown midrib corn silage on the energy balance of dairy cattle. J. Dairy Sci. 84:885-895.

Tjardes, K. E., D. D. Buskirk, M. S. Allen, N. K. Ames, L. D. Bourquin, and S. R. Rust. 2000. Brown midrib-3 corn silage improves digestion but not performance of growing beef steers. J. Anim. Sci. 78:2957-2965.

Ushida, K., B. Lassalas, and J. P. Jouany. 1985. Determination of assay parameters for RNA analysis in bacterial and duodenal sample by spectrophotometry. Influence of sample treatment and preservation. Reprod. Nutri. Develop. 25:1037-1046.

Vaage, A. S., and L. P. Milligan. 1993. An electronic device to measure the size and degree of packing of the rumen mat in cattle. Can. J. Anim. Sci. 73:655-660.

Van Soest, P. J., J. B. Robertson, and B. A. Lewis. 1991. Methods for dietary fiber and nonstarch polysaccharides in relation to animal nutrition. J. Dairy Sci. 74:3583-3597.

Wang, Z., M. L. Eastridge, and X. Qiu. 2001. Effects of forage neutral detergent fiber and yeast culture on performance of cows during early lactation. J. Dairy Sci. 84:204-212.

Welch, J. G. 1982. Rumination, particle size and passage from the rumen. J. Anim. Sci. 54:885-894.

Williams, C. H., D. J. David, and O. Iismaa. 1962. The determination of chromic oxide in feces samples by atomic absorption spectrophotometry. J. Agric. Sci. 59:381-385.

Zinn, R. A., and F. N. Owens. 1986. A rapid procedure for purine measurement and its use for estimating net ruminal protein synthesis. Can. J. Anim. Sci. 66:157-166. 